\title{
PURIFICATION AND CHARACTERIZATION OF CLONED ISOPENICILLIN N SYNTHETASE
}

\author{
Jack E. Baldwin, Stephen J. Killin, Andrew J. Pratt, \\ John D. Sutherland, Nicholas J. Turner, M. James C. Crabbe, \\ Edward P. Abraham ${ }^{\dagger}$ and Anthony C. Willis ${ }^{\dagger \dagger}$ \\ The Dyson Perrins Laboratory, \\ South Parks Road, Oxford OX1 3QY, England \\ ${ }^{\dagger}$ Sir William Dunn School of Pathology, \\ South Parks Road, Oxford OX1 3RE, England \\ "MRC Immunochemistry unit, University of Oxford, \\ South Parks Road, Oxford, OX1 3QU, England \\ (Received for publication November 11, 1986)
}

\begin{abstract}
Isopenicillin $\mathrm{N}$ synthetase (IPS) cloned from Cephalosporium acremonium has been isolated from transformed Escherichia coli and purified to homogeneity. The resulting, abundant, recombinant protein, whilst undergoing slightly different $N$-terminal processing to that observed for the fungally-derived protein, has identical kinetics for the conversion of LLD-aminoadipoyl-cysteinyl-valine to isopenicillin N. Recombinant IPS converts analogue substrates into unusual $\beta$-lactam antibiotics in exactly the same way as the fungal protein.
\end{abstract}

Isopenicillin $\mathrm{N}$ synthetase (IPS) is the enzyme responsible for the conversion of LLD-aminoadipoyl-cysteinyl-valine (1) (ACV) into isopenicillin N (2) (Scheme 1) in the biosynthesis of penicillins and cephalosporins in filamentous fungi and streptomyces ${ }^{1)}$. IPS has been purified from Cephalosporium acremonium ${ }^{2,3)}$, Penicillium chrysogenum ${ }^{4)}$ and Streptomyces clavuligerus ${ }^{5)}$ and shown to have a broad substrate specificity ${ }^{1)}$. The IPS genes from $C$. acremonium ${ }^{(2)}$ and $P$. chrysogenum ${ }^{7)}$ have been cloned and expressed in Escherichia coli RV 308. We herein report the purification, $N$-terminal sequence, kinetics and substrate specificity studies of cloned C. acremonium IPS (cIPS).

\section{Materials and Methods}

LLD-Aminoadipoyl-cysteinyl-valine and pIT337 were gifts of Eli Lilly and Co.

LLD-Aminoadipoyl-cysteinyl-aminobutyrate and LLD-aminoadipoyl-cysteinyl-allylglycine were synthesised by the method of BALDWIN et al. ${ }^{8,8)}$.

$\mathrm{SOB} / \mathrm{Kanamycin}$ agar; Tryptone $2 \%$, yeast extract $0.5 \%, \mathrm{NaCl} 0.05 \%$, Bacto agar $2 \%, \mathrm{MgSO}_{4}$ $20 \mathrm{~mm}$, kanamycin $50 \mu \mathrm{g} / \mathrm{ml}, \mathrm{pH} 7.2$.

Growth medium; Tryptone $1.6 \%$, yeast extract $1 \%, \mathrm{NaCl} 0.5 \%$, ferrous ammonium sulfate $150 \mu \mathrm{g} / \mathrm{ml}$, kanamycin $50 \mu \mathrm{g} / \mathrm{ml}$.

TA (buffer); $0.05 \mathrm{M}$ Tris- $\mathrm{HCl} \mathrm{pH} 7.7$ containing $0.02 \% \mathrm{NaN}_{3}$.

Frozen competent cells for transformation were prepared and transformed according to the

Scheme 1.<smiles>CC(C)C(NC(=O)[C@H](CS)NC(=O)CCC[C@H](C)C(=O)[O-])C(=O)O</smiles><smiles>C[C@@H](CCCC(=O)N[C@H]1C(=O)N2C1SC(C)(C)C(C(=O)O)[C@H]2C(=O)[O-])C(=O)[O-]</smiles> 
method of HANAHAN ${ }^{10)}$. Crude cell lysates of transformed strains of $E$. coli were assayed for IPS activity by bioassay. Bioassays were carried out by the hole-plate method as previously described ${ }^{2}$ except pure isopenicillin $\mathrm{N}$ was taken to have a specific activity of 100 units/mg against Staphylococcus aureus NCTC 6571 relative to cephalosporin C (potassium salt) at 10 units $/ \mathrm{mg}$.

All purification procedures were carried out at $4^{\circ} \mathrm{C}$. Centrifugation was carried out for 15 minutes at $25,000 \times g$ unless otherwise stated. Protein determinations were carried out by the method BRADFORD ${ }^{11)}$. Enzyme kinetics were measured by the $\mathrm{pH}$ stationary method of BALDwIN et al. ${ }^{12)}$ of modified by the exclusion of catalase. Kinetic parameters were determined by an integrated rate method, analysed by computer ${ }^{13}$.

Amino acid sequencing was performed using either:

1) A Beckman model $890 \mathrm{C}$ protein sequencer modified with microprocessor control and cold trap attachment. Samples were run using a double coupling program with $0.1 \mathrm{M}$ Quadrol buffer (Beckman program part No. 345802) with only minor modifications. The unstable anilinoithiazolinones (ATZ) were converted to stable phenylthiohydantoins (PTH) by the addition of $25 \%$ aqueous triffuoroacetic acid and incubation at $55^{\circ} \mathrm{C}$ for 25 minutes. All other details were as previously described $^{14)}$.

2) An Applied Biosystems 470A Protein Sequencer as previously described ${ }^{15}$ except samples were run using the 02CPTH cycle program (with minor modification) as included in the Applied Biosystems standard sequencer tape, version 2.0 software (Part No. 400355).

\section{Identification of PTH Amino Acids}

This was done by reverse phase HPLC using a $5 \times 100 \mathrm{~mm}$ Shandon ODS-Hypersil ( $5 \mu \mathrm{m}$ particle size) column equilibrated in $0.01 \mathrm{~m}$ sodium acetate, $\mathrm{pH} 4.1$, containing $10 \%$ methanol and eluted with a linear gradient of ethanol - acetonitrile $(1: 1)$ from 5 to $45 \%$ in 30 minutes at $1.0 \mathrm{ml} / \mathrm{minute}$. A Waters dual pump system generated the gradient, connected to a Waters 'WISP' 710B sample processor. The runs were controlled and integrated by a Waters 840 Data and Chromatography Control Station utilising 'Expert' software-revision 4.0 (Waters part No. 87609).

\section{Results}

\section{Host Strain Transformation and Selection}

Four strains of $E$. coli were transformed with plasmid pIT337 (Fig. 1) which has a temperature sensitive copy-number control system and expresses IPS from the Trp promoter (Table 1). Based on maximal production of isopenicillin N from ACV by crude cell lysates, JM 103 was selected as the best host strain for the preparation of recombinant IPS.

Growth of Transformed E. coli JM 103

Frozen cells were grown on SOB/kanamycin agar at $27^{\circ} \mathrm{C}$ for 18 hours. Viable colonies were used to inoculate growth medium (1 colony/10 $\mathrm{ml})$. After logarithmic growth had been obtained at $27^{\circ} \mathrm{C}$, cells were diluted $1: 50$ into fresh growth medium and grown at $37^{\circ} \mathrm{C}$ until late logarithmic phase growth had been reached. Cells harvested by centrifugation $(11,000 \times g, 20$ minutes $)$ were resuspended in TA and recentrifuged. Typically 4 liters of culture yielded $12 \sim 14 \mathrm{~g}$ cells.

\section{Purification of IPS}

Harvested cells were resuspended in TA
Fig. 1. pIT337.

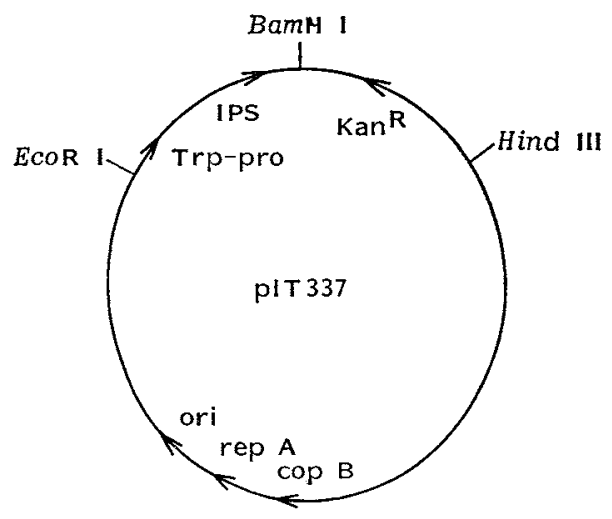


Table 1. IPS activity of Escherichia coli strains transformed with pIT337.

\begin{tabular}{|c|c|c|c|}
\hline Strain & $\mathrm{JM} 103^{\text {(8) }}$ & RV 308 & JM 101 18$\rangle \quad$ C $\left.600^{20}\right)$ \\
\hline Bioassay & $++t$ & $+t$ & No significant activity \\
\hline
\end{tabular}

Fig. 2. Sephadex G-75 purification of recombinant IPS.

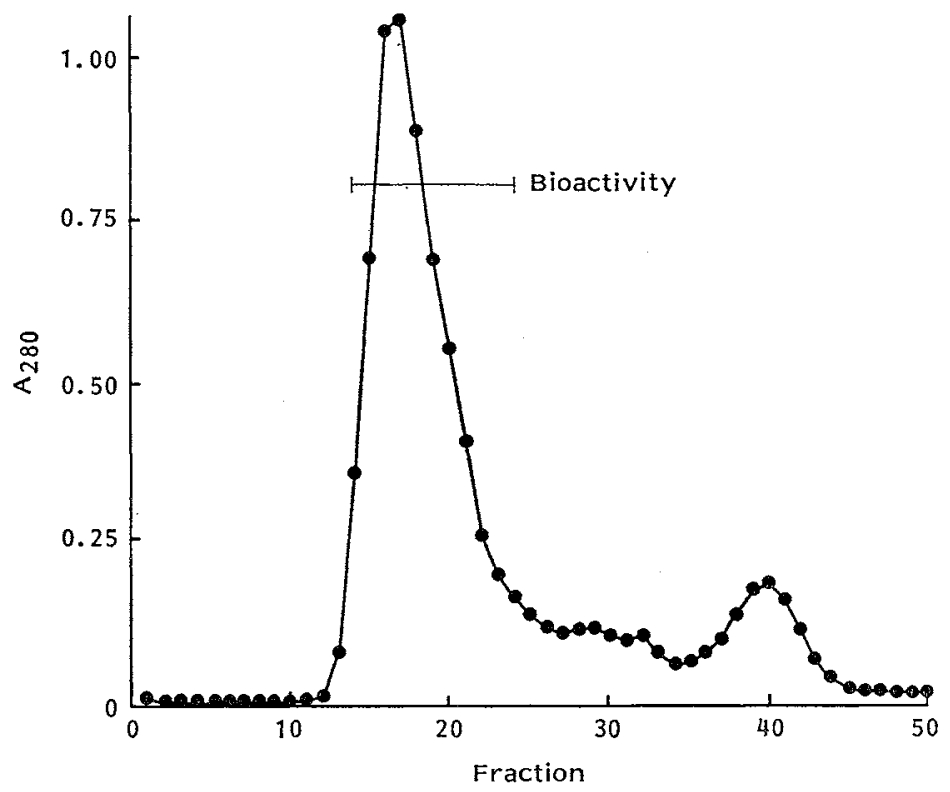

Fig. 3. DEAE-Sepharose purification of recombinant IPS.

- $\mathrm{A}_{280}, O$ conductivity.

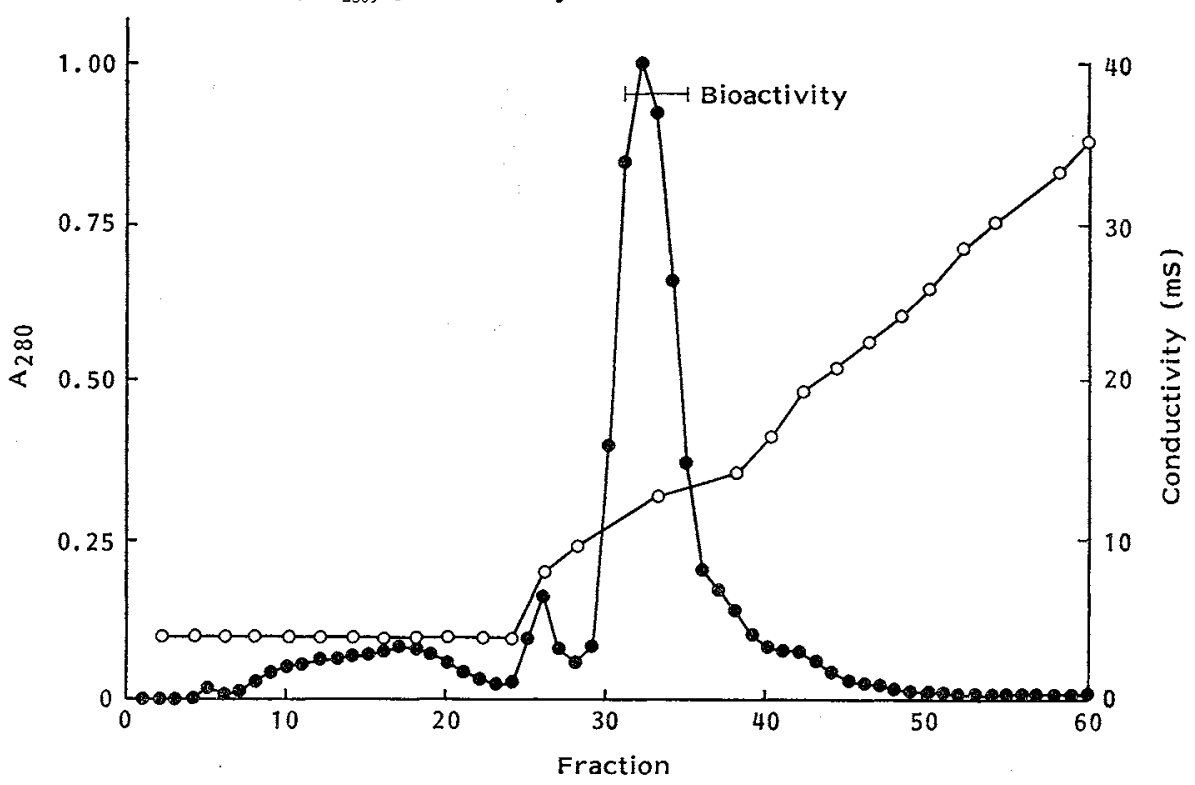

$(20 \% \mathrm{w} / \mathrm{v})$ and sonicated in three 5 -second bursts with 1 -minute rest periods. After centrifugation, the pellets were washed with TA and supernatant and washings were combined. Protamine sulfate $(5 \% \mathrm{w} / \mathrm{v})$ in TA was added to a final concentration of $1 \% \mathrm{w} / \mathrm{v}$, the $\mathrm{pH}$ was adjusted to 8.2 and the mixture was centrifuged. Ammonium sulfate was added to the supernatant to give a $55 \%$ saturated 
Table 2. Typical purification of cIPS from $12 \mathrm{~g}$ of Escherichia coli cells.

\begin{tabular}{lccc}
\multicolumn{1}{c}{ Step } & $\begin{array}{c}\text { Protein } \\
(\mathrm{mg})\end{array}$ & $\begin{array}{c}\text { Activity } \\
\text { (IU) }\end{array}$ & $\begin{array}{c}\text { Specific activity } \\
\text { (IU/mg) }\end{array}$ \\
\hline Crude extract & 159 & 38 & 0.24 \\
Protamine sulfate* & 334 & 31 & 0.09 \\
$55 \%\left(\mathrm{NH}_{4}\right)_{2} \mathrm{SO}_{4}$ supernatant & 309 & 31 & 0.10 \\
$85 \%\left(\mathrm{NH}_{4}\right)_{2} \mathrm{SO}_{4}$ precipitate & 118 & 23 & 0.20 \\
Sephaderx G-75 pool & 70 & 11 & 0.16 \\
DEAE-Sepharose pool & 21 & 12 & 0.59 \\
\hline
\end{tabular}

* Protamine sulfate increases the protein concentration leading to reduced specific activities at the protamine sulfate and $55 \%$ ammonium sulfate stages.

Fig. 4. SDS-Polyacrylamide gel electrophoresis ${ }^{16)}$ of IPS samples at various stages of purification.

Tracks: 1) Molecular weight markers 12.3, 17.2, 30, 45, 66.2 and $77 \mathrm{k}$ daltons; 2) crude extract; 3) protamine sulfate treated; 4) $55 \%\left(\mathrm{NH}_{4}\right)_{2} \mathrm{SO}_{4}$ supernatant; 5) $85 \%\left(\mathrm{NH}_{4}\right)_{2} \mathrm{SO}_{4}$ precipitate; 6) bioactive Sephadex G-75 fraction; 7) bioactive DEAE-Sepharose fraction; 8) molecular weight markers.

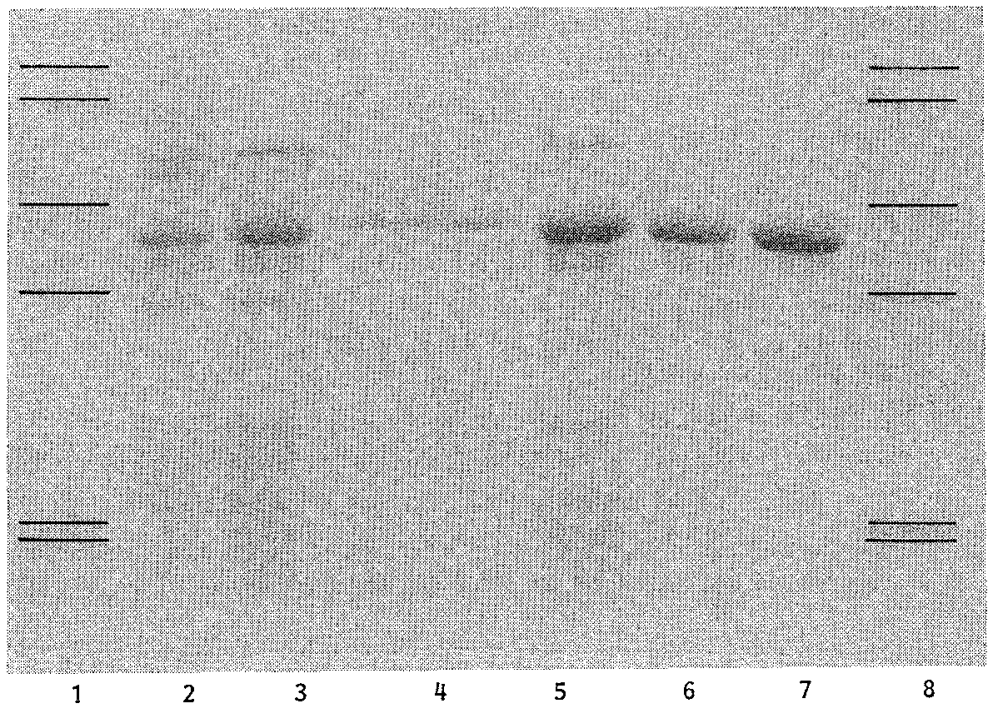

solution. The supernatant after centrifugation was adjusted to $85 \%$ saturation with ammonium sulfate. The pellet isolated by centrifugation was resuspended in TA and IPS activity was obtained in a clear solution after further centrifugation.

The homogeneous solution was applied to a Sephadex G-75 column and eluted with TA. Fractions were monitored by absorbance at $280 \mathrm{~nm}$ and by bioassay (Fig. 2). Fractions containing IPS activity were pooled and applied to a DEAE-Sepharose fast flow column. The column was washed with TA containing $0.05 \mathrm{M} \mathrm{NaCl}$ and eluted with a linear $\mathrm{NaCl}$ gradient $(0.05 \sim 0.25 \mathrm{M})$ (Fig. 3). Fractions containing IPS activity were pooled and concentrated on a PM 10 membrane in an Amicon concentrator.

Samples were stored at $-70^{\circ} \mathrm{C}$ with no appreciable loss of activity over several months. The specific activity of the purified enzyme was $0.45 \sim 0.6 \mathrm{IU} / \mathrm{mg}$. Details of a typical purification are given in Table 2. SDS-Polyacrylamide gel electrophoresis ${ }^{2,3,18)}$ of fractions from each stage of purification are shown in Fig. 4. 


\section{Amino Terminal Sequence of Recombinant IPS}

Recombinant IPS was found to have a homogeneous $\mathrm{N}$ terminus. The first 20 amino acids were found to correspond exactly with the sequence predicted from the DNA sequence after loss of the terminal methionine residue (Fig. 5).

\section{Incubation of Analogue Substrates}

To an aqueous solution of tripeptide (1 mg), dithiothreitol (DTT, $8.3 \mathrm{mM}$ ) and ammonium bicarbonate $(50 \mathrm{~mm}, 1.2 \mathrm{ml})$ was added $5 \mathrm{mM} \mathrm{FeSO}_{4}(0.1 \mathrm{ml}), 50 \mathrm{~mm}$ ascorbic acid $(0.1 \mathrm{ml})$ and catalase (3,000 Sigma units $/ \mathrm{ml}, 0.05 \mathrm{ml})$. Recombinant IPS ( $5 \mathrm{IU})$, exchanged into $50 \mathrm{~mm}$ ammonium bicarbonate $(3.5 \mathrm{ml})$, was added and the mixed reaction mixture was divided in two and each portion was shaken at $27^{\circ} \mathrm{C}$ ( $4 \mathrm{~Hz}, 20$ minutes). More DTT $(0.05 \mathrm{ml}, 100 \mathrm{~mm})$ and $\mathrm{FeSO}_{4}(0.05 \mathrm{ml}, 5 \mathrm{~mm})$ was added to each sample and the mixture was shaken for a further 25 minutes.

The reactions were terminated by removal of IPS using an Amicon Micropartition system at $4^{\circ} \mathrm{C}(2,000 \times g, 10 \text { minutes })^{17)}$. The sample was lyophilised and resuspended in $\mathrm{D}_{2} \mathrm{O}(0.6 \mathrm{ml})$. NMR was performed on $0.5 \mathrm{ml}$. In each case the remaining sample gave positive bioassays.

\section{Discussion}

E. coli JM 103 transformed with plasmid pIT337 produces IPS as the major protein component. The high degree of expression considerably simplifies purification allowing large amounts of IPS to be purified to homogeneity in 2 days. In addition $E$. coli is a more convenient source of IPS than fungi or streptomyces since it requires greatly decreased growing times.

Amino terminal sequencing of recombinant IPS was carried out to confirm the integrity of the sample and to identify the nature of $N$-terminal processing. In $C$. acremonium mature IPS has undergone loss of the terminal methionine and glycine residues. Recombinant IPS was found to have

Fig. 5. N-Terminal amino acid sequence of IPS.

1) Sequence predicted from DNA sequence, 2) sequence determined from IPS purified from Cephalosporium acremonium $\mathrm{CO} 728^{5}, 11$, 3) sequence determined from IPS purified from Escherichia coli JM 103.

1) Met Gly Ser Val Pro Val Pro Val Ala Asn Val Pro Arg Ile Asp Val Ser Pro Leu Phe Gly ...

2) Ser Val Pro Val Pro Val Ala Asn Val Pro Arg Ile Asp Val Ser Pro Leu Phe Gly ...

3) Gly Ser Val Pro Val Pro Val Ala Asn Val Pro Arg Ile Asp Val Ser Pro Leu Phe Gly

Scheme 2.<smiles>CCC(NC(=O)[C@H](CS)NC(=O)CCC[C@H]([NH3+])C(=O)[O-])C(=O)O</smiles>

3<smiles>C[C@@H](CCCC(=O)N[C@@H]1C(=O)N2C(C(=O)O)[C@H](C)S[C@H]12)C(=O)[O-]</smiles>

4

IPS

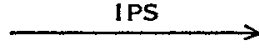


a homogeneous $N$-terminus, however $N$-terminal processing differed from that observed for fungally derived enzyme ${ }^{8,12)}$. In $E$. coli the terminal methionine residue is removed but the second residue, glycine, is not. This result is in keeping with observations for other cloned proteins, containing small uncharged penultimate amino terminal residues, expressed in $E$. coli ${ }^{18}$. The different processing observed in $E$. coli had no apparent consequences on the biochemical properties of the enzyme. The $K m$ of recombinant IPS for the conversion of ACV to isopenicillin N (Scheme 1) at pH 7.7 was found to be 0.166 土 0.01 , identical within experimental error to that found for the fungal enzyme ${ }^{12)}$.

Incubation of LLD-aminoadipoyl-cysteinylaminobutyrate (3) with recombinant IPS generates both penam (4) and cepham (5) products in a 3:1 ratio, identical to the reaction catalysed by the fungal protein (Scheme 2$)^{8)}$. The NMR spectra of the crude reaction mixtures for each case are shown in Fig. 6. This result demonstrates that the direct production of cepham compounds from tripeptides is an enzymic process catalysed by IPS and not some artifact of
Fig. 6. ${ }^{1} \mathrm{H}$ NMR from incubation of 3 with IPS.

${ }^{1} \mathrm{H}$ NMR spectra $\left(500 \mathrm{MHz}, \mathrm{D}_{2} \mathrm{O}\right)$ of crude incubation mixtures of 3 with IPS [Upper; fungal IPS. Lower; recombinant IPS] after purification from protein. The characteristic $\beta$-lactam resonances are labelled. The ratio 4:5 was approximately $3: 1$ in each case.

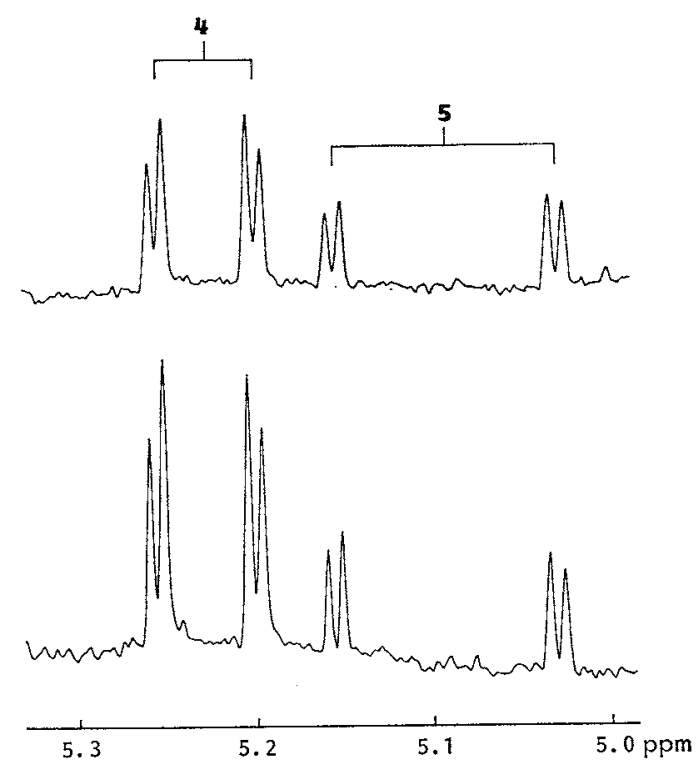

Fig. 7. ${ }^{1} \mathrm{H}$ NMR from incubation of 6 with IPS.

${ }^{1} \mathrm{H}$ NMR spectra $\left(500 \mathrm{MHz}, \mathrm{D}_{2} \mathrm{O}\right)$ of crude incubation mixtures of 6 with IPS [Upper; fungal IPS. Lower; recombinant IPS] after purification from protein. The characteristic $\beta$-lactam resonances are labelled. The ratio $7: 8: 9: 10 \mathrm{a}: 10 \mathrm{~b}: 11$ was approximately $4: 1: 2: 10: 1: 5$ in each case.

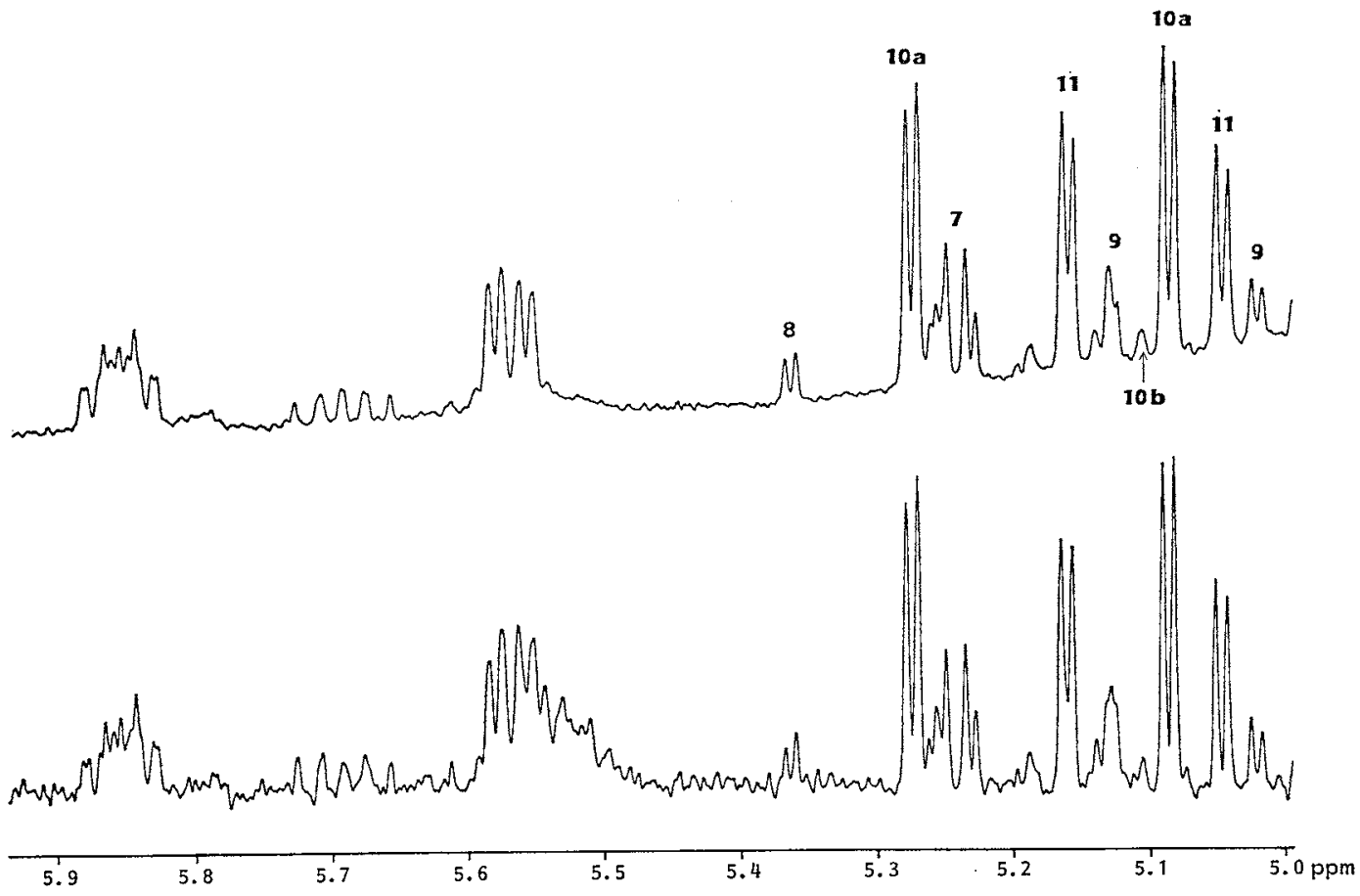


Scheme 3.<smiles>C=CCC(NC(=O)C(CS)NC(=O)CCC[C@H](N)C(=O)[O-])C(=O)O</smiles>

6<smiles>C[As](C)(C)C</smiles><smiles>C=C[C@H]1SC2C(NC(=O)CCC[C@H](N)C(=O)[O-])C(=O)N2C1C(=O)O</smiles>

7<smiles>N[C@@H](CCCC(=O)N[C@@H]1C(=O)N2C(C(=O)O)CC(CO)S[C@H]12)C(=O)[O-]</smiles>

9<smiles>C=C[C@H]1SC2C(NC(=O)CCC[C@H](N)C(=O)[O-])C(=O)N2C1C(=O)O</smiles>

8<smiles>N[C@@H](CCCC(=O)N[C@H]1C(=O)N2C(C(=O)O)C=CCS[C@H]12)C(=O)[O-]</smiles>

$10 a, 10 b$ (epimers)<smiles>C[C@H](CCCC(=O)N[C@@H]1C(=O)N2C(C(=O)O)CC(O)CS[C@H]12)C(=O)[O-]</smiles>

11

previous fungal extracts.

Confirmation that unusual $\beta$-lactams detected in previous incubations of analogue tripeptides ${ }^{1)}$ are generated by various competing pathways all catalysed by IPS was strongly supported by the incubation of LLD-aminoadipoyl-cysteinyl-allylglycine (6) with recombinant IPS. In this case six $\beta$-lactam products are produced by the fungal enzyme, arising from both dehydrogenase $(\mathbf{7}, \mathbf{8}, \mathbf{1 0 a}$ and $10 \mathrm{~b}$ ) and monooxygenase $(9 \text { and 11) pathways (Scheme } 3)^{9)}$. NMR analysis of the crude mixture produced under analogous conditions with recombinant IPS shows an identical product ratio (Fig. 7). These results demonstrate that IPS alone actively catalyses production of the varied range of $\beta$-lactam products found in previous, in vitro, studies with analogue substrates, confirming the versatility of this enzyme for producing new antibiotics.

The availability of large quantities of homogeneous recombinant IPS provides material for X-ray crystallography and other structural studies of the enzyme. The substrate specificity studies reveal the opportunity for larger scale production of unusual $\beta$-lactams from analogue tripeptides.

\section{Acknowledgements}

We would like to acknowledge the support and cooperation of Eli Lilly and Co., especially Dr. T. INGoLIA in this work*. We acknowledge receipt of funding by the SERC. The amino acid sequencing facilities of the MRC immunochemistry unit were made available by Dr. K. REID.

* Using an alternative purification of cIPS, Dr. INGOLIA and colleagues have verified the details of $N$-terminal processing described here. (Frolik, C. A.; S. M. Samson, R. M. VanFrank, M. W. Warwick, M. L. SLISZ \& T. D. InGOLIA: Unpublished results.) 


\section{References}

1) BALDWIN, J.E.: Recent advances in penicillin biosynthesis. In Recent Advances in the Chemistry of B-Lactam Antibiotics. Third International Symposium, 1984. Eds., A. G. Brown \& S. M. Roberts, pp. $62 \sim 85$, The Royal Society of Chemistry, London, 1985

2) Pang, C. P.; B. Chakravarti, R. M. Adlington, H. H. Ting, R. L. White, G. S. Jayatilake, J. E. Baldwin \& E. P. ABraham: Purification of isopenicillin N synthetase. Biochem. J. 222: 789 795, 1984

3) Hollander, I. J.; Y.-Q. Shen, J. Heim, A. L. Demain \& S. Wolfe: A pure enzyme catalyzing penicillin biosynthesis. Science 224: 610 612, 1984

4) RAmos, F. R.; M. J. LóPez-Nieto \& J. F. MaRTíN： Isopenicillin N synthetase of Penicillium chrysogenum, an enzyme that converts $\delta$-(L- $\alpha$-aminoadipyl)-L-cysteinyl-D-valine to isopenicillin N. Antimicrob. Agents Chemother. 27: 380 387, 1985

5) Wolfe, S.; D. W. S. WeStlake \& S. E. JENSEN (M.I.T.): Isolation of cyclase, epimerase and a ring expansion enzyme for producing unnatural cephalosporins. U.S. 4,510,246, Apr. 9, 1985

6) Samson, S. M.; R. Belagaje, D. T. Blankenship, J. L. Chapman, D. Perry, P. L. Skatrud, R. M. VanFrank, E. P. Abraham, J. E. Baldwin, S. W. Queener \& T. D. Ingolia: Isolation, sequence determination and expression in Escherichia coli of the isopenicillin $\mathrm{N}$ synthetase gene from Cephalosporium acremonium. Nature 318: $191 \sim 194,1985$

7) Carr, L. G.; P. L. Skatrud, M. E. Scheetz, S. W. Queener \& T. D. Ingolia: Cloning and expression of the isopenicillin N synthetase gene from Penicillium chrysogenum. Gene 48: 191 194, 1986

8) Baldwin, J. E.; E. P. Abraham, R. M. Adlington, B. Chakravarti, A. E. Derome, J. A. Murphy, L. D. Field, N. B. Green, H. H. Ting \& J. J. Usfer: Penicillin biosynthesis. Dual pathways from a modified substrate. J. Chem. Soc. Chem. Commun. 1983: 1317 1319, 1983

9) Baldwin, J. E.; R. M. Adlington, A. E. Derome, H. H. Ting \& N. J. Turner: Penicillin biosynthesis: Multiple pathways from a modified substrate. J. Chem. Soc. Chem. Commun. 1984: 1211 1214, 1984

10) Hanahan, D.: Techniques for transformation of E. coli. In DNA Cloning Volume 1: A Practical Approach. Ed., D. M. Glover, pp. 109 136, IRL Press, Oxford, 1985

11) BRADFORD, M. M.: A rapid and sensitive method for the quantitation of microgram quantities of protein utilising the principle of protein-dye binding. Anal. Biochem. 72: $248 \sim 254,1976$

12) Baldwin, J. E.; S. E. Moroney \& H. H. TinG: A coupled enzyme assay for isopenicillin N synthetase. Anal. Biochem. 145: 183 187, 1985

13) Crabbe, M.J.C.: The analysis of enzyme reactions. In Microcomputers in Biology: A Practical Approach. Eds., C. R. IRELAND \& S. P. LoNG, pp. $107 \sim 149$, IRL Press, Oxford, 1984

14) Christie, D. L. \& J. GAGNon: Isolation, characterisation and N-terminal sequences of the CNBr cleavage peptides from buman compliment factor B. Biochem. J. $201: 555 \sim 567,1982$

15) Hewick, R. M.; M. W. Hunkapiller, L. E. Hoon \& W. J. Dreyer: A gas-liquid solid phase peptide and protein sequenator. J. Biol. Chem. 256: 7990 7997, 1981

16) LABMMLI, U.K.: Cleavage of structural proteins during the assembly of the head of bacteriophage T4. Nature 227:680 685, 1970

17) Petchey, M. \& M. J. C. Crabbe: Analysis of carbohydrates in lens, erythrocytes, and plasma by highperformance liquid chromatography of nitrobenzoate derivatives. J. Chromatogr. 307: 180 184, 1984

18) Flinta, C.; B. Persson, H. Jornvall \& G. Von Heirne: Sequence determinants for cytosolic N-terminal protein processing. Eur. J. Biochem. 154: 193 196, 1986

19) Messing, J.: New M13 vectors for cloning. Methods Enzymol. 101: 20 78, 1983

20) Appleyard, R. K.: Segregation of new lysogenic types during growth of a doubly lysogenic strain derived from Escherichia coli K12. Genetics 39: 440 452, 1954 